Bangladesh J. Bot. 43(1): 9-17, 2014 (June)

\title{
BREEDING FOR PREMATURE FLOWERING RESISTANT LINES WITH IMPROVED FIBRE YIELD AND QUALITY IN TOSSA JUTE (CORCHORUS OLITORIUS L.)
}

\author{
T BEGUM* AND D KUMAR \\ Central Research Institute for Jute and Allied Fibres, Barrackpore, \\ Kolkata-700 120, West Bengal, India
}

Key words: Breeding, Elite lines, Fibre quality, Fibre yield, Premature flowering resistance

\begin{abstract}
Ten diverse tossa jute genotypes of different eco-geographic origin were crossed with four well adapted varieties as testers to produce $40 \mathrm{~F}_{1} \mathrm{~S}$ in line $\times$ tester mating design. Based on general and specific combining ability, 10 desirable cross combinations were selected and carried forward up to $\mathrm{F}_{4}$ generation by modified bulk method for further selection. Out of 890 selected promising single plant progenies from different cross combinations at $\mathrm{F}_{5}$ generation, 223 were further selected for premature flowering resistance and better growth performance over the ruling checks by sowing them at middle of March. Among 223 promising lines, 13 were short listed based on fibre yield and fibre quality parameters. Yield performance of these elite lines evinced that six lines viz. JRO 2405, JRO 2402, JRO 2404, JRO 2602, JRO 2406 and JRO 2407 were critically different from both the check varieties, JRO 524 and JRO 8432. These six high yielding lines having comparable or better fibre quality and showing resistance to premature flowering enabled them to be most suitable to fit in multiple cropping systems. Out of these 6 elite lines, JRO 2407 was identified as a new variety of tossa jute.
\end{abstract}

\section{Introduction}

Jute is a versatile, environment friendly, fibre crop and is one of the leading cash crops of India. It is the cheapest bast fibre and most important vegetable fibre crop in the world next to cotton in terms of usage, global consumption, production and availability (Ahmed and Nizam 2008). It is a biodegradable and renewable ligno-cellulosic fibre (Mir et al. 2008). Jute fibre is obtained from the bark of Corchorus olitorius L. (tossa jute) and C. capsularis L. (white jute) (Palve and Sinha 2005). Earlier tossa jute, a short day crop, was possible to sow only after middle of April and the acreage in favour of tossa jute was only $40 \%$ of the total jute acreage in the country (Ghosh 1983). But tossa jute generally flowers prematurely when sown before the middle of April. Long duration and premature flowering traits made this crop unsuitable for multiple cropping systems. To fit paddy after jute in multiple cropping systems three $C$. olitorius varieties i.e. JRO (Jute Research Olitorius) 878, JRO 7835 and JRO 524 (Chakraborty and Ghosh 1969) were bred in the 70's and two more tossa jute varieties i.e. JRO 8432 (Chowdhury and Das 2003) and JRO 128 were released in 1999 and 2002, respectively (Kar et al. 2010) incorporating premature flowering resistance from 'Sudan Green', an exotic germplasm from Sudan, Africa and 'Tanganyika 1', an exotic strain from Tanzania, Africa, permitting sowing in middle of March. These varieties were widely accepted by the farmers due to high yield and suitability to fit jute in crop rotation with transplanted Aman (wet-season) paddy. Thus the trait premature flowering resistance offered early sowing of tossa jute avoiding the risk of premature flowering i.e. without

*Author for correspondence. <tamina@live.in> 
hampering vegetative growth (fibre formation) as well enabled jute to be fitted in multiple cropping sequences which ultimately boosted the productivity (Karmakar et al. 2008, Kar et al. 2009). Development and acceptance of these premature flowering resistant and early sowing varieties dramatically converted the area under jute cultivation from the domain of white to tossa jute. As a result, the present acreage in favour of tossa jute is $85 \%$ of the total jute area (Ghosh 1983). National productivity went on increasing, the balance between capsularis and olitorius are titled towards the latter, which is now $10: 90$ per cent (Karmakar et al. 2008). With the advent of globalization and the growing concern for ecological and environmental security there is increasingly renewed interest worldwide for the production of jute and its diversified uses including industrial applications. Jute varieties with improved fibre quality are of great demand for production of diversified value added products. Therefore, development of premature flowering resistant lines with higher fibre yield and better fibre quality in tossa jute is an important breeding objective of the jute breeders. In other words, restructuring of plant type having broad genetic base from diverse sources with a definite prospect of obtaining higher yield and better fibre quality is the prime objective of jute breeding. In an attempt to select transgressive segregates, diverse genotypes of different eco-geographic origin with known potentiality for different desirable attributes were crossed in line $\times$ tester mating design and on the basis of combining ability, desirable cross combinations were selected (Kumar et al. 2002) to be carried forward for further selection.

The present investigation aims at developing premature flowering resistant lines of tossa jute along with improved fibre yield and quality from the selected cross combinations and thereby to refurbish high yielding better fibre quality varieties capable of being sown earlier than the existing varieties without risk of premature flowering rendering them to be better fitted in multiple cropping systems as well industrial applicability.

\section{Materials and Methods}

Ten diverse tossa jute genotypes viz. Juta nonsoong, JRO 620, JRO 66, Palmate leaf, KEN/SM/024, TAN/X/087, Selection-2, BC-3, JRO 3352 and JRO 52 of different eco-geographic origin with known potentiality for high fibre yield, finer fibre quality, resistance to biotic/abiotic stresses and resistance to premature flowering were crossed with four well adapted varieties viz. JRO 524, JRO 878, JRO 632 and JRO 7835 as testers to produce $40 \mathrm{~F}_{1} \mathrm{~s}$ in line $\times$ tester mating design in the year 1999 (Kumar et al. 2002). The experimental materials were derived from the germplasm pool of Central Research Institute for Jute and Allied Fibres (CRIJAF), Barrackpore, Kolkata, West Bengal, India. All 40 hybrids and their 14 parents were grown together in randomized block design (RBD) with three replications in rainy season of 2000 at CRIJAF Farm, Barrackpore, Kolkata, West Bengal, India $\left(22^{\circ} 45^{\prime} \mathrm{N}\right.$ and $\left.88^{\circ} 26^{\prime} \mathrm{E}\right)$. On the basis of general and specific combing ability, 10 desirable cross combinations (KEN/SM/024 $\times$ JRO 524, KEN/SM/024 × JRO 878, Selection-2 $\times$ JRO 878, Selection-2 $\times$ JRO 632, BC-3 $\times$ JRO 524, JRO $2352 \times$ JRO 632, JRO $3352 \times$ JRO 7835, JRO $52 \times$ JRO 524, JRO $52 \times$ JRO 878 and JRO $52 \times$ JRO 632) were chosen from these 40 crosses and were carried forward up to $F_{4}$ generation by modified bulk method in which some selections were made instead of allowing the population entirely on nature. At $\mathrm{F}_{4}$ generation in 2003-04, 89 individuals from each cross were selected on the basis of visual agro-morphological characters mainly plant height, basal diameter and growth performance.

Eight hundred ninety selected promising single plant progenies at $F_{5}$ were evaluated at the same location by growing them under appropriate thermo-photoperiodic regime by sowing in middle of March, 2004 with ruling check varieties, JRO 524 and JRO 8432 to assess the degree of 
premature flowering resistance of these lines. Vegetative growth for at least 100 days before switching over to reproductive phase was considered to be optimum resistance to premature flowering. On this basis, out of 890 promising lines, 223 premature flowering resistant lines were identified as they flowered after 100 days. The selected lines were grown in RBD with 3 replications in 2005-06. Fifty eight elite lines were further selected on the basis of visual observation on plant height and growth performance. Ten random plants were harvested from each of these 58 lines and two check varieties i.e. JRO 524 and JRO 8432. Data were recorded for plant height $(\mathrm{cm})$, base diameter $(\mathrm{cm})$, green weight $(\mathrm{g})$, fibre yield $(\mathrm{g})$ and fibre percentage. Fibre yield data i.e. dry fibre weight and dry stick weight were recorded after extraction and drying of fibre and stick. The proportion of dry fibre weight of ten plants to dry fibre plus dry stick weight of these ten plants or the fibre percentage was considered as an appropriate measure of harvest index. Fibre quality parameters viz. fibre strength (g/tex) and fibre fineness (tex) of these 58 lines were assessed at National Institute of Research for Jute and Allied Fibres Technology, Kolkata, India. Fibre fineness is the diameter of the filament measured from the replicated samples by airflow method, while fibre strength is calculated as the breaking load of the fibre sample divided by the linear density of the unstrained fibre which is referred to as its tenacity. This trait was determined by fibre bundle strength tester which gives an average value of fibre strength of different fibre samples.

Out of 58, thirteen lines (sl. nos. 2, 8, 9, 12, 14, 35, 43, 45, 46, 47, 48, 50 and 57) having higher fibre yield and higher values for other traits of study were selected further.

These 13 promising lines in $\mathrm{F}_{7}$ having premature flowering resistance with better fibre quality were subjected to microplot yield trial along with ruling check varieties, JRO 524 and JRO 8432 in 2006-07 in RBD with 3 replications at Central Seed Research Station for Jute and Allied Fibres, Budbud, Burdwan, West Bengal, India $\left(22^{\circ} 30^{\prime} \mathrm{N}\right.$ and $\left.88^{\circ} 26^{\prime} \mathrm{E}\right)$. The sowing was done in middle of March. The plot size was $3.0 \mathrm{~m} \times 4.5 \mathrm{~m}$. Row to row and plant to plant distances were $30 \mathrm{~cm}$ and $5-7 \mathrm{~cm}$, respectively. Net plots were harvested and plot yield data were recorded.

In each generation the significance test (F test), standard error (SE), critical difference (CD) and coefficient of variation (CV\%) of all the parameters under study were carried out following Gomez and Gomez (2010).

\section{Results and Discussion}

Average performance of fibre yield and yield contributing characters of 58 selected premature flowering resistant lines of $C$. olitorius jute in $\mathrm{F}_{6}$ (Table 1) revealed that selections 2, 8, 9 and 12 from the cross combination, KEN/SM/024 $\times$ JRO 524, and selections 14 and 35 from the cross combination KEN/SM/024 $\times$ JRO 878 evinced higher values for fibre yield and some yield contributing characters, medium value for fibre strength and lower value for fibre fineness.

A few selections viz. 43, 45, 46, 47, 48, 50 and 57 from the cross combinations BC $3 \times$ JRO 524, JRO $3352 \times$ JRO 632, JRO $3352 \times$ JRO 7835, JRO $52 \times$ JRO 524, JRO $52 \times$ JRO 878 and JRO $52 \times$ JRO 632 exhibited higher and desirable values for maximum number of yield contributing characters and fibre quality parameters. These 13 lines were short listed on the basis of high yield, yield components and quality traits (Table 2). It may be mentioned here that the germplasms, Sudan Green and Tanganyika 1, were utilized so far, as resistant source in breeding premature flowering resistant variety. The newly bred lines combined high yield with premature flowering resistance from KEN/SM/024 (Kumar 2004) and finer fibre quality from JRO 878. Fibre yield of all 13 short listed promising lines evinced higher values over the check varieties (Table 2). Fibre strength of 4 promising lines viz. JRO 2407 and JRO 2502 from the cross 
Table 1. Average performance of fibre yield, yield contributing characters and fibre quality parameters of 58 selected premature flowering resistant lines of $C$. olitorius in $\mathrm{F}_{6}$ generation.

\begin{tabular}{|c|c|c|c|c|c|c|c|c|}
\hline $\begin{array}{l}\text { Sl. } \\
\text { No. }\end{array}$ & Pedegree & $\begin{array}{l}\text { Fibre yield } \\
\text { (g) }\end{array}$ & $\begin{array}{c}\text { Fibre } \\
(\%)\end{array}$ & $\begin{array}{l}\text { Plant } \\
\text { height } \\
(\mathrm{cm})\end{array}$ & $\begin{array}{l}\text { Base } \\
\text { diam. } \\
(\mathrm{cm})\end{array}$ & $\begin{array}{c}\text { Green } \\
\text { weight } \\
\text { (g) }\end{array}$ & $\begin{array}{c}\text { Fibre } \\
\text { strength } \\
\text { (g/tex) }\end{array}$ & $\begin{array}{c}\text { Fibre } \\
\text { fineness } \\
\text { (tex) }\end{array}$ \\
\hline 1 & $\begin{array}{l}\mathrm{KEN} / \mathrm{SM} / 024 \times \\
\mathrm{JRO} 524\left(\mathrm{~F}_{6}\right)\end{array}$ & 12.10 & 34.09 & 310.07 & 1.24 & 141.00 & 30.00 & 2.80 \\
\hline 2 & , & 12.07 & 31.61 & 323.60 & 1.23 & 169.83 & 26.40 & 3.10 \\
\hline 3 & , & 11.57 & 29.40 & 306.93 & 1.23 & 161.17 & 25.00 & 2.70 \\
\hline 4 & , & 11.50 & 32.74 & 310.23 & 1.18 & 155.00 & 28.20 & - \\
\hline 5 & , & 9.97 & 33.29 & 302.33 & 1.17 & 139.00 & 27.32 & 2.80 \\
\hline 6 & , & 11.27 & 33.14 & 328.10 & 1.23 & 162.50 & 27.20 & 2.75 \\
\hline 7 & , & 9.63 & 30.22 & 300.43 & 1.24 & 149.50 & 27.50 & 2.70 \\
\hline 8 & , & 12.00 & 30.57 & 308.17 & 1.27 & 147.50 & 26.30 & 2.90 \\
\hline 9 & , & 12.03 & 30.53 & 318.53 & 1.29 & 156.67 & 25.80 & 3.10 \\
\hline 10 & , & 9.93 & 30.63 & 322.87 & 1.35 & 141.17 & 24.00 & 2.50 \\
\hline 11 & , & 11.57 & 32.91 & 318.93 & 1.20 & 158.67 & 26.40 & 2.80 \\
\hline 12 & , & 12.43 & 31.83 & 323.77 & 1.34 & 147.83 & 23.70 & 2.80 \\
\hline 13 & $\begin{array}{l}\mathrm{KEN} / \mathrm{SM} / 024 \times \\
\mathrm{JRO} 878\left(\mathrm{~F}_{6}\right)\end{array}$ & 11.90 & 33.19 & 311.77 & 1.32 & 150.50 & 27.80 & 2.60 \\
\hline 14 & , & 12.47 & 34.23 & 312.07 & 1.26 & 160.83 & 26.50 & 2.80 \\
\hline 15 & , & 10.23 & 31.91 & 303.33 & 1.28 & 136.67 & 26.60 & 2.60 \\
\hline 16 & , & 8.37 & 30.39 & 287.97 & 1.21 & 114.33 & 25.60 & - \\
\hline 17 & , & 11.47 & 31.05 & 308.50 & 1.20 & 150.00 & 26.63 & 3.10 \\
\hline 18 & , & 9.70 & 29.35 & 338.83 & 1.27 & 139.40 & 27.40 & 2.70 \\
\hline 19 & , & 10.03 & 30.52 & 316.73 & 1.21 & 126.33 & 25.50 & 2.70 \\
\hline 20 & , & 9.70 & 30.62 & 314.40 & 1.32 & 137.17 & 25.75 & 2.70 \\
\hline 21 & , & 10.67 & 30.29 & 322.00 & 1.29 & 145.17 & 26.00 & 2.60 \\
\hline 22 & , & 9.33 & 29.55 & 303.27 & 1.39 & 140.67 & 26.60 & 2.60 \\
\hline 23 & , & 9.40 & 31.69 & 304.03 & 1.30 & 117.00 & 29.16 & 2.70 \\
\hline 24 & , & 10.03 & 32.14 & 301.33 & 1.30 & 137.33 & 23.20 & 2.70 \\
\hline 25 & , & 11.40 & 32.88 & 323.40 & 1.22 & 134.67 & 25.35 & 2.90 \\
\hline 26 & , & 8.97 & 29.48 & 297.67 & 1.17 & 118.50 & 27.40 & - \\
\hline 27 & , & 9.60 & 27.95 & 314.17 & 1.37 & 134.67 & 27.85 & 2.50 \\
\hline 28 & , & 9.53 & 33.02 & 311.87 & 1.32 & 124.67 & 25.20 & 3.20 \\
\hline 29 & , & 9.30 & 32.59 & 317.33 & 1.29 & 119.67 & - & - \\
\hline 30 & , & 9.57 & 31.75 & 316.17 & 1.37 & 133.67 & 27.60 & 2.70 \\
\hline 31 & , & 9.30 & 32.23 & 301.83 & 1.28 & 153.83 & 24.30 & 2.30 \\
\hline 32 & , & 10.90 & 33.43 & 319.83 & 1.26 & 139.97 & 24.60 & - \\
\hline 33 & , & 8.97 & 32.56 & 316.50 & 1.22 & 119.67 & 25.40 & 2.60 \\
\hline 34 & , & 13.10 & 31.38 & 345.50 & 1.44 & 155.33 & 26.40 & 3.60 \\
\hline 35 & , & 12.90 & 29.86 & 338.00 & 1.39 & 180.17 & 27.60 & 2.20 \\
\hline
\end{tabular}


(Contd.)

\begin{tabular}{|c|c|c|c|c|c|c|c|c|}
\hline 36 & $\begin{array}{l}\text { Selection-2 } \times \\
\text { JRO } 632\left(F_{6}\right)\end{array}$ & 9.43 & 29.52 & 330.83 & 1.16 & 127.67 & 25.90 & 2.20 \\
\hline 37 & , & 8.50 & 30.02 & 308.17 & 1.25 & 128.33 & 25.50 & - \\
\hline 38 & , & 11.60 & 32.79 & 341.67 & 1.35 & 153.00 & 25.80 & 2.90 \\
\hline 39 & , & 9.63 & 26.65 & 300.00 & 1.29 & 145.67 & 28.00 & 2.70 \\
\hline 40 & , & 9.47 & 30.72 & 329.50 & 1.34 & 139.67 & 24.00 & 2.50 \\
\hline 41 & , & 8.80 & 31.41 & 300.50 & 1.15 & 126.67 & 26.20 & 2.20 \\
\hline 42 & , & 11.03 & 29.28 & 339.67 & 1.19 & 161.17 & 29.49 & 2.90 \\
\hline 43 & $\begin{array}{l}\text { BC-3 } \times \\
\text { JRO } 524\left(F_{6}\right)\end{array}$ & 12.53 & 30.43 & 339.67 & 1.24 & 155.67 & 25.60 & 3.30 \\
\hline 44 & ,, & 11.97 & 32.95 & 334.83 & 1.16 & 146.67 & 27.20 & 3.10 \\
\hline 45 & $\begin{array}{l}\text { JRO } 3352 \times \\
\text { JRO } 632\left(\mathrm{~F}_{6}\right)\end{array}$ & 13.20 & 33.77 & 347.17 & 1.36 & 184.50 & 27.00 & 3.10 \\
\hline 46 & , & 12.77 & 28.87 & 341.33 & 1.31 & 194.00 & 24.25 & 2.60 \\
\hline 47 & $\begin{array}{l}\text { JRO } 3352 \times \\
\text { JRO } 7835\left(\mathrm{~F}_{6}\right)\end{array}$ & 12.70 & 28.08 & 344.67 & 1.35 & 193.07 & 23.70 & 2.40 \\
\hline 48 &, & 12.80 & 29.37 & 327.00 & 1.28 & 172.67 & 25.20 & 2.70 \\
\hline 49 & $\begin{array}{l}\text { JRO-52 × JRO } \\
524\left(\mathrm{~F}_{6}\right)\end{array}$ & 11.93 & 32.85 & 325.87 & 1.27 & 164.33 & 24.30 & 2.60 \\
\hline 50 & $\begin{array}{l}\text { JRO } 52 \times \\
\text { JRO } 878\left(\mathrm{~F}_{6}\right)\end{array}$ & 12.63 & 32.14 & 339.00 & 1.28 & 201.67 & 26.00 & 2.80 \\
\hline 51 & ,, & 9.77 & 28.90 & 324.00 & 1.27 & 154.10 & 26.90 & 2.60 \\
\hline 52 & , & 9.37 & 25.96 & 326.00 & 1.13 & 133.67 & 26.20 & 2.50 \\
\hline 53 & , & 10.00 & 30.33 & 327.50 & 1.19 & 144.00 & 27.60 & 3.00 \\
\hline 54 & $\begin{array}{l}\text { JRO } 52 \times \text { JRO } \\
632\left(\mathrm{~F}_{6}\right)\end{array}$ & 12.10 & 31.21 & 330.50 & 1.24 & 174.67 & 29.30 & 2.90 \\
\hline 55 & , & 10.97 & 31.14 & 320.83 & 1.25 & 190.00 & 25.70 & 2.90 \\
\hline 56 & , & 8.93 & 30.10 & 324.03 & 1.19 & 120.33 & 29.40 & 2.70 \\
\hline 57 & , & 13.20 & 32.75 & 306.50 & 1.16 & 138.50 & 25.00 & 2.90 \\
\hline 58 & , & 14.27 & 30.73 & 327.50 & 1.24 & 145.00 & 25.30 & 2.75 \\
\hline 59 & $\begin{array}{l}\text { JRO } 524 \\
\text { (Check var. 1) }\end{array}$ & 9.77 & 29.57 & 287.55 & 1.15 & 115.33 & 26.40 & 3.40 \\
\hline 60 & $\begin{array}{l}\text { JRO } 8432 \\
\text { (Check var. 2) }\end{array}$ & 11.10 & 31.17 & 310.33 & 1.13 & 121.67 & 27.10 & 2.80 \\
\hline \multicolumn{2}{|c|}{ F. test } & HS & HS & NS & NS & HS & & \\
\hline \multicolumn{2}{|c|}{ Std. error } & 0.77 & 1.14 & 14.67 & 0.11 & 9.24 & & \\
\hline \multicolumn{2}{|c|}{ S.E. difference } & 1.09 & 1.61 & 20.75 & 0.15 & 13.07 & & \\
\hline \multicolumn{2}{|c|}{$C D(p=0.05)$} & 2.17 & 3.19 & 41.08 & 0.30 & 25.87 & & \\
\hline \multicolumn{2}{|c|}{$\mathrm{CV} \%$} & 12.37 & 6.37 & 7.97 & 14.91 & 10.87 & & \\
\hline
\end{tabular}

HS denotes highly significant and NS not significant.

combination KEN/SM/024 × JRO 878 as well JRO 2504 from the cross JRO $3352 \times$ JRO 632 were superior to the check variety, JRO 524. But only one line, JRO 2502 showed higher tenacity over both the check varieties. On the other hand, 4 lines namely JRO 2502, JRO 2505, JRO 2601 and JRO 2602 recorded higher fineness over both the check varieties.

Performance of these short-listed lines in microplot yield trial evinced highly significant differences among themselves for fibre yield indicating the presence of genotypic difference (Table 3). Some of the promising lines viz. JRO 2405, JRO 2402, JRO 2404, JRO 2602, JRO 2406 


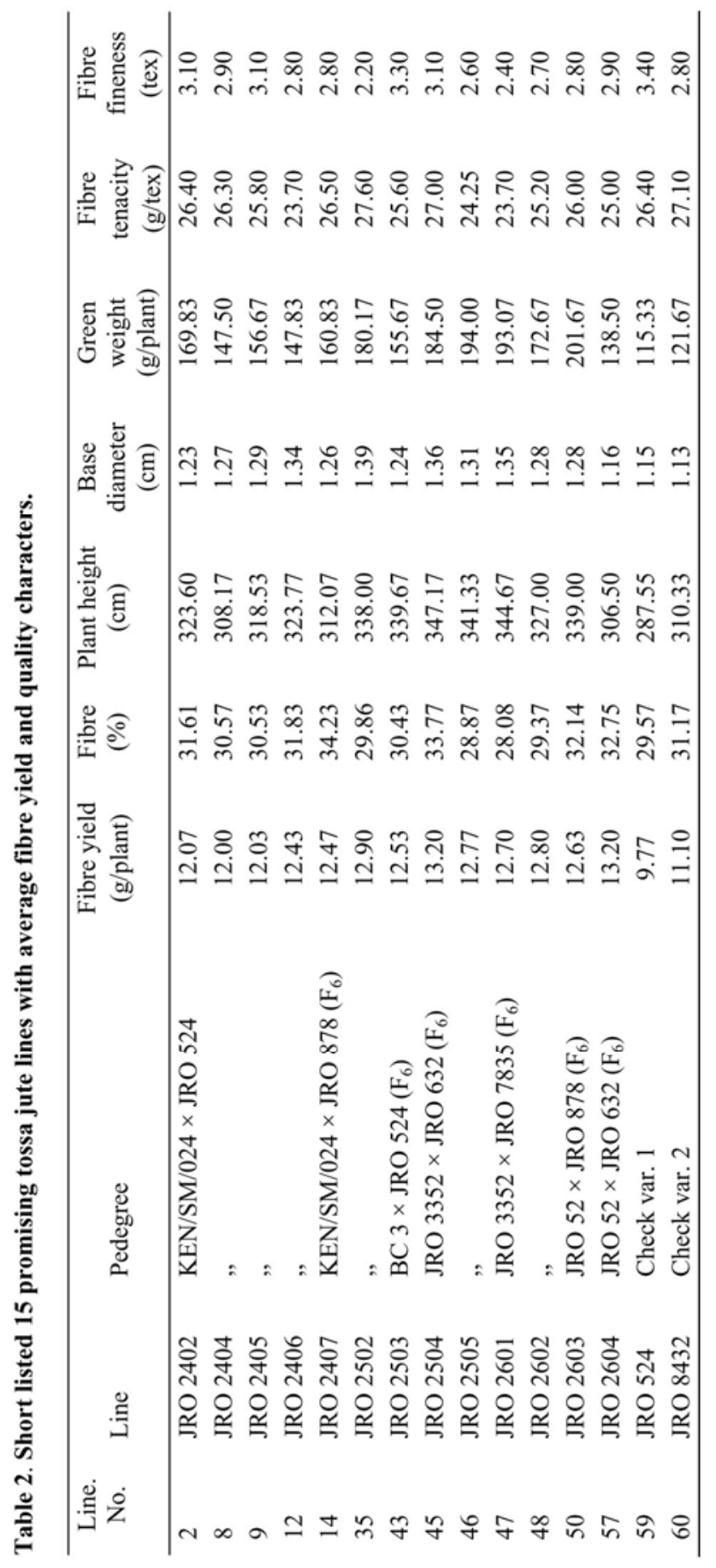


and JRO 2407 yielded significantly and critically higher than the ruling check varieties and outyielded JRO 524 by $25.20-37.47 \%$ and JRO 8432 by $19.03-30.67 \%$. Their fibre quality was also comparable with the check varieties. Out of these 6 high yielding lines, 5 were selected from crosses between exotic germplasm and well adapted variety. All these 6 lines showing premature

Table 3. Performance of the selected elite tossa jute lines with regard to average fibre yield and fibre quality.

\begin{tabular}{|c|c|c|c|c|c|}
\hline \multirow{2}{*}{$\begin{array}{l}\text { Line/ } \\
\text { variety }\end{array}$} & \multirow{2}{*}{$\begin{array}{l}\text { Fibre yield } \\
\text { (q/ha) }\end{array}$} & \multicolumn{2}{|c|}{ Increased \% over ruling check varieties } & \multirow{2}{*}{$\begin{array}{l}\text { Fibre tenacity } \\
\text { (g/tex) }\end{array}$} & \multirow{2}{*}{$\begin{array}{l}\text { Fibre fineness } \\
\text { (tex) }\end{array}$} \\
\hline & & JRO 524 & JRO 8432 & & \\
\hline JRO 2402 & 28.16 & 35.19 & 28.53 & 26.40 & 3.10 \\
\hline JRO 2404 & 27.62 & 32.60 & 26.06 & 26.30 & 2.90 \\
\hline JRO 2405 & 28.63 & 37.47 & 30.67 & 25.80 & 3.10 \\
\hline JRO 2406 & 26.08 & 25.20 & 19.03 & 23.70 & 2.80 \\
\hline JRO 2407 & 26.08 & 25.20 & 19.03 & 26.50 & 2.80 \\
\hline JRO 2502 & 21.06 & 1.10 & -3.88 & 27.60 & 2.20 \\
\hline JRO 2503 & 22.69 & 8.93 & 3.56 & 25.60 & 3.30 \\
\hline JRO 2504 & 25.00 & 20.02 & 14.10 & 27.00 & 3.10 \\
\hline JRO 2505 & 18.13 & -12.96 & -17.25 & 24.25 & 2.60 \\
\hline JRO 2601 & 21.99 & 5.57 & 0.37 & 23.70 & 2.40 \\
\hline JRO 2602 & 26.93 & 29.28 & 22.91 & 25.20 & 2.70 \\
\hline JRO 2603 & 22.38 & 7.44 & 2.15 & 26.00 & 2.80 \\
\hline JRO 2604 & 24.69 & 18.53 & 12.69 & 25.00 & 2.90 \\
\hline $\begin{array}{l}\text { JRO } 524 \\
\text { (Check var. 1) }\end{array}$ & 20.83 & - & -5.18 & 26.40 & 3.40 \\
\hline $\begin{array}{l}\text { JRO } 8432 \\
\text { (Check var. 2) }\end{array}$ & 21.91 & -4.93 & - & 27.10 & 2.80 \\
\hline \multicolumn{6}{|c|}{ F test $=$ Highly significant } \\
\hline \multicolumn{6}{|l|}{$\mathrm{SE}(\mathrm{m}) \pm=1.26$} \\
\hline \multicolumn{6}{|c|}{$\mathrm{CD}(\mathrm{P}=0.05)=3.65$} \\
\hline $\mathrm{CV} \%=14.84$ & & & & & \\
\hline
\end{tabular}

flowering resistance in mid-March sowing were found suitable for sowing even earlier than the existing varieties without any risk of premature flowering and thereby allowing transplantation of paddy after jute in multiple cropping sequences. Out of these 6 promising lines, JRO 2405 and JRO 2407 had been qualified as most outstanding lines in IET (Initial Evaluation Trial), AVT-I (Advanced Varietal Trial-I), AVT-II and Adaptive trials. In February, 2011 identification proposal of these two varieties were submitted in the AINP workshop for release. Out of these two varieties JRO 2407 has been identified for release as a new variety for entire tossa jute growing belt of the country.

With the advent of intensive agriculture and introduction of multiple cropping system jute crop faced competition from other major crops and pushed back more and more to the poor and marginal land. The inevitable result was the fall in productivity. It was then felt necessary to fit jute crop in multiple cropping sequences. A jute crop should be harvested by middle of July if one desires to transplant the 'aman' ('wet-season') paddy as successive crop. In jute, maximum fibre production takes place during the period starting from flowering to early pod stage (Maiti and Mitra 1972, Mitra and Maiti 1974) and usual harvest time is at 50\% pod stage which used to fall 
during mid-August to end-August allowing a crop minimum of 135 days growth (Kumar et al. 1994). Therefore, to fit paddy after jute it was felt necessitate to develop new jute varieties, which could be sown earlier than mid-April. But being a short day crop sowing of tossa jute earlier than mid-April induces premature flowering, which is highly undesirable for jute crop grown for fibre and is hence not suitable for areas where jute must be sown early to release the land for the next crop. Therefore, it was essential to develop new tossa jute varieties suitable for early sowing i.e. in mid-March without any risk of premature flowering which will be suitable in multiple cropping sequences and able to release of land for rice cultivation. Such varieties will be harvested by midJuly allowing hardly 120 days crop growth which will also fit in multiple cropping sequences. In the present study the newly identified tossa jute variety, JRO 2407 derived from the cross between $\mathrm{KEN} / \mathrm{SM} / 024 \times \mathrm{JRO} 878$, is an early maturing, premature flowering resistant variety having better fibre quality suitable for multiple cropping system. This new variety combined high yield with premature flowering resistance from KEN/SM/024 (Kumar 2004) and finer fibre quality from JRO 878. Interestingly the fibre fineness of this new variety is 2.80 tex which is superior to the available premature flowering resistant early sowing tossa jute varieties like JRO 524 (fineness is 3.40 tex), JRO 7835 (fineness is 3.50 tex) (Begum and Kumar 2011). This finer and stronger fibre may be utilized for the production of finer count blended yarn. Seed sample of JRO 2407 was sent to NBPGR and the National Identity number- IC 587431 was received.

Therefore, it may be inferred that the newly identified tossa jute variety, JRO 2407, developed from the heterogenous base population from different eco-geographic origin having wider genetic base and premature flowering resistance is suitable for early March sowing. The variety can replace the cultivated varieties like JRO 524 and JRO 8432 for higher yield and better quality of fibre. If this variety is sown in early March, it will be more profitable than the existing varieties used in multiple cropping and will be widely accepted by the farmers due to its higher fibre yield coupled with finer fibre quality and suitability to fit in the crop rotation with transplanted Aman (wet-season) paddy. Besides, it will meet the great demand of jute industry for production of diversified and value added products.

\section{References}

Ahmed Z and Nizam SA 2008. Jute - Microbiological and biochemical reserach. Plant Tissue Cult. \& Biotech. 18: 197-220.

Begum T and Kumar D 2011. Usefulness of morphological characteristics for DUS testing of jute (Corchorus olitorius L. and C. capsularis L.). Span. J. Agric. Res. 9: 473-483.

Chakraborty K and Ghosh T 1969. Chaitali tossa - a new jute variety. Indian Farming 19: 26-27.

Chowdhury SK and Das BB 2003. JRO 8432 (Shakti) tossa jute: A new high yielding variety for early sowing. Indian Farming 53: 19-20.

Ghosh T 1983. Handbook of Jute. Plant Production and Protection. Paper No. 51, pp 29-31, Food and Agriculture Organization of the United Nations, Rome, Italy.

Gomez KA and Gomez AA 2010. Statistical procedures for agricultural research (2 ${ }^{\text {nd }}$ edition). John Wiley Inc., pp. 20-30.

Kar CS, Kundu A, Sarkar D, Sinha MK and Mahapatra BS 2009. Genetic diversity in jute (Corchorus spp) and its utilization: A review. Indian J. Agril. Sci. 79: 575-586.

Kar CS, Satya P, Mitra J, Sarkar D, Sinha MK, Kundu A and Mahapatra BS 2010. Varietal development of jute and allied fibres in India. Indian Farming 59: 5-9.

Karmakar PG, Hazra SK, Sinha MK and Chaudhury SK 2008. Breeding for quantitative traits and varietal development in jute and allied fibre crops. In: Jute and Allied Fibres Updates: Production and Technology (eds: Karmakar PG, Hazra SK, Ramasubramanian T, Mandal RK, Sinha MK and Sen HS). Central Research Institute for Jute and Allied Fibres, Barrackpore, Kolkata, India. pp. 57-75. 
Kumar D 2004. JRO 2345 (INGR No. 04050; IC 296659), a jute (Corchorus olitorius L.) germplasm line devoid of premature flowering. Indian J. Plant Genet. Resources 17: 233.

Kumar D, Saha A and Basak SL 1994. Breeding of tossa jute (Corchorus olitorius) for an early maturing high yielding variety. Bangladesh J. Jute Fib. Res. 19: 67-70.

Kumar D, Gupta D and Saha A 2002. Choice of parents and hybrids from line $\times$ tester crosses for improving fibre yield in jute (Corchorus olitorius L.). J. Interacad. 6: 406-411.

Maiti RK and Mitra GC 1972. Cambial activity in relation to the production of fibre bundles at different phases of growth in white jute (Corchorus capsularis L.). Bull. Bot. Soc. Bengal 26: 79-85.

Mir RR, Rustgi S, Sharma S, Singh R, Goyal A, Kumar J, Tyagi AK, Khan H, Sinha MK, Balyan HS and Gupta PK 2008. A preliminary genetic analysis of fibre traits and the use of new genomic SSRs for genetic diversity in jute. Euphytica 161: 413-427.

Mitra GC and Maiti RK 1974. Cambial activity in relation to yield potential in tossa jute (Corchorus olitorius L.). Bull. Bot. Soc. Bengal 28: 35-39.

Palve SM and Sinha MK 2005. Genetic variation and interrelationships among fibre yield attributes in secondary genepool of Corchorus spp. SABRAO Journal of Breeding and Genetics 37: 55-64.

(Manuscript received on 4 October, 2012; revised on 19 January, 2014) 